\title{
Plevral Sıvı Sitolojisi Vakalarımızın Retrospektif Analizi
}

\author{
Retrospective Analysis of Pleural Fluid Cytology
}

\section{Serdar YANIK ${ }^{1}$, Ozan TURGUT ${ }^{2}$, Aybala Ağaç AY ${ }^{3}$, Suat DURKAYA ${ }^{4}$, Akın ÇAM ${ }^{5}$, Turgut KARACA ${ }^{6}$, Elif CANBOLANT ${ }^{7}$}

\author{
${ }^{1}$ Iskenderun Devlet Hastanesi, Patoloji Bölümü, HATAY \\ ${ }^{2}$ Iskenderun Devlet Hastanesi, Kadın Doğum Kliniği, HATAY \\ ${ }^{3}$ Kırlkkale Üniversitesi Tip Fakültesi, Genel Cerrahi Anabilim Dall, KIRIKKALE \\ ${ }^{4}$ Iskenderun Devlet Hastanesi, Gögü̈ Cerrahi Kliniği, HATAY \\ ${ }^{5}$ Iskenderun Devlet Hastanesi, Dâhiliye Kliniği, HATAY

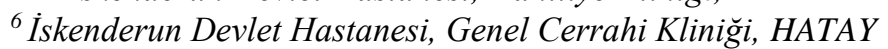

\begin{abstract}
ÖZET
Plevral sıvıların sitolojik incelemesi tanı koymada hızlı ve etkili bir yöntemdir. Plevra sıv1 ve biyopsi materyallerinin incelenmesi etyolojiyi saptamak için en sık kullanılan yöntemlerdendir. $\mathrm{Bu}$ çalışmanın amacı, plevral efüzyonlarda sitopatolojik tanı dağılımını yaş,cinsiyet gibi parametreler göz önünde bulundurarak araştırmaktır.

İskenderun Devlet Hastanesi Patoloji Laboratuvarında retrospektif olarak 1 Ocak 2012-1 Kasım 2013 tarihleri arasında tanı alan 36 plevral sıvı olgusu çalışma grubu olarak belirlendi. Değerlendirme sonuçları yetersiz, benign, atipik, kuşkulu ve malign şeklinde beş gruba ayrılarak biyopsi sonuçlarıyla karşılaştırıldı.

Toplam 36 plevral sıv1 olgusunun 13'ü $(\% 36,11)$ kadın, 23’ü $(\% 63,89)$ erkekti. Yaş aralığı 16-89 olup, genel ortalama 60,72 idi. Sitolojide olguların 5 'ine $(\% 13,89)$ yetersiz (aselülarite), 5 'ine atipik $(\% 13,89), 21$ 'ine $(\% 58,33)$ benign, 3'üne $(\% 8.33)$ kuşkulu ve 2 'sine $(\% 5,56)$ malign tanıs1 verildi. Malign tanısı alan olguların ikisi de metastatik karsinom olup, biri akciğerin küçük hücreli kanseri diğeri ise meme kanseri metastazıydı. Olgularımızda yaş ortalaması, yetersiz tanisi alan vakalarda 73,6, atipik tanisı alanlarda 58,8, benign tanısı alan vakalarda 57.28, kuşkulu tanısı alan vakalarda 67.33, akciğer kanseri olan erkek hastamızın yaşı 68 , meme kanseri olan kadın hastamızın yaşı 51 olmak üzere malign tanısı alan vakalarımızda ise 59,50 olarak saptandı. Olgularımızın genel yaş ortalamas 1se 60,72 olarak saptand1. Olgularımızda atipi tanısı alan vakalardan birisi daha sonra akciğer tümörü tanısı almış olup atipik tanısı ve şüpheli tanısı alan diğer vakalara ait kanser tanısı kayıtlarımızda mevcut değildir. Bunların dışında plevral sitoloji yapılmamış ama plevraya akciğer ve memeden metastaz yapmış 2 adet malign vakamızda bulunmaktadır.

Sonuç olarak plevral sitoloji plevrayı tutan malignitelerin saptanmasında çok önemli bir tanı yöntemi olup bölgemizde malign plevral effüzyonun en s1k iki nedeni akciğer ve meme kanseri metastazidır.
\end{abstract}

Anahtar Kelimeler: Plevral effüzyon, sitopatoloji, histopatoloji
ABSTRACT
Cytological examination of pleural fluids is a fast and efficient diagnostic method.Investigation of pleural fluid cytologies and pleural biopsies are the most common methods to determine etiology aim of this study was to investigate the distribution of cytopathologicdiagnoses with age,sex parameters in pleural effusions

A total of 36 pleural fluid cases diagnosed from 1 January 2012 to 1 October 2013 in İskenderun Government Hospital Pathology Laboratory were enrolled to the study. Results were classified in 5 groups as inconclusive, benign, atypical, suspicious and malignant, and compared with the biopsy results. Of the total 36 pleural fluid cases, 13 (36.11\%) were females and $23(63.89 \%)$ were males. The age range was between 16 and 89 with a mean value of 60.72 . Of the cases, $5(13.89 \%)$ were diagnosed as inadequate, $21(58.33 \%)$ benign, 5 atypical (13.89\%), $3(8.33 \%)$ suspicious, and $2(5.56 \%)$ malignant by cytology. The cases who were diagnosed as malignant were reported as metastatic carcinoma and one of these was small cell carsinoma of lung and the other one was breast carsinoma.Inadequate materials were $73.6 \%$ of the cases, while atypical cytology was in $58.8 \%$ and benign $57.28 \%$ of the cases. The average age of the cases was 60.72 .

Of the 5 cases reported as atypical, biopsy result of 1 showed lung cancer and there was no cancer diagnosis belongs to the cases reported as atypical and suspicious. Exept these cases we have two malignant cases who were diagnosed as pleural metastasis of lung cancer and breast cancer but not performed a pleural cytology

Cytological examination of pleural fluids is a very important diagnostic method to determine pleural malignancies and the two most common reasons of malignant pleural effusion are lung and breast cancer in our region.

Keywords: Pleural effusion, cytopathology, histopathology
KÜ Tıp Fak Derg 2014; 16(1): 1-4

Geliş Tarihi / Received: 26.11.2013

Kabul Tarihi / Accepted: 02.01.2014
Yazışma Adresi / Correspondence: Sami YANIK İskenderun Devlet Hastanesi, Patoloji Bölümü, HATAY

E-posta: izomera@hotmail.com Tel: 05555871717 


\section{GíRiș}

Plevra akciğerleri ve torasik kaviteyi kaplayan seröz bir membrandır. Plevral sıvı iki plevral tabaka arasında ince bir tabaka halinde bulunmaktadır (1). Plevrada sıv1 birikmesi, s1k rastlanan ancak etyolojisi her zaman saptanamayan klinik bir problemdir. Plevra sıv1 ve biyopsi materyallerinin incelenmesi etyolojiyi saptamak için en sık kullanılan yöntemlerdendir (2). Plevral sıvıların sitolojik incelemesi tanı koymada hızlı ve etkili bir yöntemdir. Eksudatif tarzda plevral sıvı birikimi inflamasyon veya tuberküloz, pnömoni, malignite, pankreatit, pulmoner infarkt ve sistemik lupus eritematozis gibi hastalıklarda görülebilmektedir (3). Plevral effüzyon nedenleri ülkeler arasında değişiklik göstermektedir. Gelişmiş ülkelerde tüberküloz plöreziler son sıralarda yer bulurken ülkemizde daha sık rastlanabilmektedir (4-6). Standart plevral effüzyon sitolojisi malign plevral effüzyonu saptayabilmekle beraber malign plevral effüzyonlu hastaların ancak \% 65'inde tanısaldır. Çeşitli çalışmalarda bu rakamın \% 62-90 arasında değişiklik gösterdiği belirtilmektedir ${ }^{7}$. Bu çalışmanın amacı, plevral effüzyonlarda sitopatolojik tanı dağılımını ve sito-histopatolojik korelasyon oranını yaş, cinsiyet gibi parametrler göz önünde bulundurarak değerlendirmektir.

Tablo 1: Plevral sitoloji olgularında cinsiyet dağılımı

\section{OLGULAR VE YÖNTEM}

İskenderun Devlet Hastanesi Patoloji Laboratuvarında retrospektif olarak 1 Ocak 2012-1 Kasım 2013 tarihleri arasında tanı alan 36 plevral sıvı olgusu çalışma grubu olarak belirlendi. Değerlendirme sonuçları yetersiz, benign, atipik, kuşkulu ve malign şeklinde beş gruba ayrılarak biyopsi sonuçlarıyla karşılaştırıldı.

\section{BULGULAR}

Toplam 36 plevral sıvı olgusunun 13'ü $(\% 36,11)$ kadın, 23’ü $(\% 63,89)$ erkekti (Tablo 1). Yaş aralığı 16-89 olup, genel ortalama 60.72 olarak saptand1. Sitolojide olguların 5'ine $(\% 13,89)$ yetersiz (aselülarite), 5'ine atipik (\%13.89), 21'ine (\%58.33) benign, 3'üne $(\% 8,33)$ kuşkulu ve2’sine (\% 5.56) malign tanısı verildi (Tablo 2 ). Malign tanısı alan olguların ikiside metastatik karsinom olup biri akciğerin küçük hücreli kanseri diğeri ise meme kanseri metastazıyd. Olgularımızda atipi tanısı alan vakalardan birisi daha sonra akciğer tümörü tanısı almış olup atipik tanısı ve şüpheli tanısı alan diğer vakalara ait kanser tanısı kayıtlarımızda mevcut değildir. Bunların dışında plevral sitoloji yapılmamış ama plevraya akciğer ve memeden metastaz yapmış 2 adet malign vakamızda bulunmaktadır.

\begin{tabular}{llcc}
\hline & Kadın (\%) & Erkek $(\%)$ & Toplam \\
\hline Plevral sivi sitolojisi & $13(36,11)$ & $23(63,89)$ & 36 \\
\hline
\end{tabular}

Tablo 2: Plevral sitoloji olgularında tanısal alt gruplar

\begin{tabular}{lcccccc}
\hline & Yetersiz (\%) & Benign (\%) & Atipik (\%) & Kuşkulu (\%) & Malign (\%) & Toplam \\
\hline Plevral sıvı sitolojisi & $5(13,89)$ & $21(58,33)$ & $5(13,89)$ & $3(8,33)$ & $2(5,56)$ & 36 \\
\hline
\end{tabular}


Tablo 3: Plevral sitoloji olgularında tanısal alt gruplarda yaş ortalamaları

\begin{tabular}{lcccccc}
\hline & Yetersiz & Benign & Atipik & Kuşkulu & Malign & Toplam \\
\hline Plevral sıv1 sitolojisi & 73,60 & 57,28 & 58,80 & 67,30 & 59,50 & 60,72 \\
\hline
\end{tabular}

Olgularımızda yetersiz tanısı alan vakaların yaş ortalaması 73,6, atipik tanısı alanların yaş ortalaması 58,8 , benign tanısı alan vakaların yaş ortalaması 57,28 , kuşkulu tanısı alan vakaların yaş ortalaması 67,33, akciğer kanseri olan erkek hastamızın yaşı 68, meme kanseri olan kadın hastamızın yaşı 51 olmak üzere malign tanısı alan vakalarımızın yaş ortalaması ise 59,50 olarak saptandı. Olgularımızın genel yaş ortalaması ise 60,72 olarak saptand 1 (Tablo 3).

\section{TARTIŞMA}

Plevral effüzyon etyolojisi bölgelere göre değişiklikler göstermektedir (4-6). Plevral effüzyonlar birçok hastalığa bağlı oluşabilmekte ve \%20'leri bulan oranlarda etyoloji net olarak aydınlatılamamaktadır. Pnömoni, kalp yetmezliği ve karaciğer hastalığı gibi hastalıklar vakaların \%80'ni oluştururken malignite ile ilişkili sebepler kalan \%20’yi oluşturmaktadır (1). Arbak ve arkadaşları primer akciğer karsinomlarının malign plevral efüzyon sebepleri sıralamasında plevraya metastaz yapmış kanserlerin önünde ilk sırada olduğunu ifade etmişlerdir (8). Bayrak ve arkadaşları malign plevral effüzyonlarda akciğer kanserini en sık neden olarak bulmuşlardır (9). Bizim çalışmamızda malign plevral efüzyon tanısı alan iki vakadan biri akciğerin küçük hücreli kanseri diğeri de meme kanseri metastazı olmak üzere metastatik kanserlerdir.

Uzunlar ve arkadaşları 161 olgudan oluşan çalışmalarında ortalama yaşı 54,57 olarak bildirmişlerdir (2). Adams ve arkadaşları 92 olgudan oluşan çalışmalarında ortalama yaşı 60 olarak saptamışlardır (10). Dağlı F A ve arkadaşlarının yaptığı çalışmada ortalama yaşı $58,4 \pm 17,8$ olmakla birlikte yaş aralığı15-89 arasında değişmekteydi (1).Olgularımızda en küçük yaş 16 en büyük yaş 89 olup ortalama yaş 60,72 'dir.

Olgularımızda 36 plevral mayiinin 13’ü $(\% 36,11)$ bayan ve 23’ü $(\% 63,89)$ erkekti. Dağlı F A ve arkadaşlarının yaptığı çalışmada ise 298 olgunun 114 $(\% 38,3)$ tanesi bayan ve $184(\% 61,7)$ tanesi erkekti (1). Olgularımızda 36 plevral mayiinin 5'ine $(\% 13,89)$ yetersiz (aselülarite), 5'ine atipik (\%13,89), 21'ine $(\% 58,33)$ benign, 3’üne $(\% 8,33)$ kuşkulu ve 2’sine $(\%$ 5,56) malign tanısı verildi. Dağlı F A ve arkadaşlarının yaptığı çalışmada olguların 3'üne (\%1) yetersiz, 8'ine atipik (\%2,7), 246’sina benign (\%82,6), 10’una (\% 3,4) kuşkulu ve 31 'ine $(\% 10,4)$ malign tanısı verildi (1).

Bizim çalışmamızda plevral sitoloji uygulanmış 2 malign olgunun 2 'sinde de (\%100) plevral sitoloji pozitif sonuç verdi. Ayrıca plevral biopsi ile 2 malign olgunun 2'side pozitif sonuç vermiştir. Görülen malign vakaların 2'si akciğer, 2'side meme kanseri metastazı olarak tanı almış olup bu kanser türleri literatür ile uyumludur. Ardıç ve arkadaşları yaptıkları çalışmada, 44 malign plörezili hastanın \%63,6'sında malign hücre izlenmiş, ayrıca plevral biyopsi ile 38 malign olgunun toplam \%68,42'sinde biyopsiyle tanı sağlanmıştır (11). Uzunlar ve arkadaşları 54 malign olgusunun 30'unda $(\% 55,56)$ plevra sitoloji pozitif sonuç alındığını bildirmişlerdir (2). Dağlı F A ve arkadaşlarının yaptığ çalışmada 298 vakanın 31 tanesinin malign plevral effüzyona sahip olduğu, bunların $24(\% 8,1)$ tanesinin metastatik karsinom $7(\% 2,3)$ tanesinin ise malign mezotelyoma olduğu bildirilmiştir (1).

Malign plevra sıvılarında sitolojik incelemenin tanı değeri \%9-80, plevra biyosisinin ise \%11-70 arasında değişmektedir (3). Marel ve arkadaşları 171 plevra sıvısını inceledikleri çalışmada, plevral sıvı sitolojisinin tanıyı ortaya koymada plevra biyopsisi, 
bronkoskopi, mikrobiyoloji ve biyokimyadan daha fazla değere sahip olduğunu ileri sürmüşlerdir (12). Uzunlar ve arkadaşlarının yaptığı çalışmada, malign sıvılarda sitolojinin tanı değeri \%55,56, biyopsinin ise \%59,25'dir (2). Polatlı ve arkadaşları çalışmalarında malign sıvılarda sitolojinin tanı değerini \%85,14; biyopsinin ise \%76,74 olarak saptamışlardır (13). Bizim çalışmamızda bu değerler hem sitoloji hem biopsi için daha yüksek (\%100) çıkmış olup bu değerlerin yüksekliği kanser vakamızın daha az olmasına bağlanmıştır.

Sonuç olarak plevral sitoloji plevrayı tutan malignitelerin saptanmasında çok önemli bir tanı yöntemi olup bölgemizde malign plevral efüzyonun en sık iki nedeni akciğer ve meme kanseri metastazıdır.

\section{KAYNAKLAR}

1. Dağlı AF, Küçük Ş, Sezer $M$, Üçer Ö. Cytopathologic diagnosis in pleural effusion and cyto-histopathologic correlation plevral efüzyonda sitopatolojik tanı ve sito-histopatolojik korelasyon. Türk Patoloji Dergisi. 2011; 27(1): 12-6.

2. Uzunlar A.K, Büyükbayram H, Kırbaş G, Yaldız M, Yılmaz F, Arslan A. Plevral Sivı Sitolojisi ve Biyopsisinin Tanı Değeri: Bir Retrospektif Çalışma. Solunum Hastalıkları. 2000; 11: 169-73.

3. Light RW, Macgregor MI, Luchsinger PC, Ball WC. Pleural effusions: the diagnostic separation of transudates and exudates. Ann Intern Med. 1972; 77: 507-13.

4. Çakır EE, Yılmam İ, Çağlar T, Altıay G. Trakya üniversitesi tıp fakültesi gögüs hastalıkları servisinde 15 yıllık süreçte yatırılarak izlenen plevral effüzyonlu hastaların değerlendirilmesi. İzmir Göğüs Hastanesi Dergisi. 2009; 23(2): 51-7.

5. Gönlügür TE, Gönlügür U. 454 plevral efüzyonun retrospektif analizi. İnönü Üniversitesi Tıp Fakültesi Dergisi. 2007; 14(1): 21-5.
6. Metintaș S. Plevral sıvıların epidemiyolojisi Plevra hastalıkları. Ankara: Toraks Kitapları-Toraks Derneği Yayınları. 2003: 16-23.

7. Bakır K. Malign plevral effüzyonların tanısında sitopatoloji. Türk Toraks Derneği Tedavi Bülteni. 2009; 3(2): 9-12

8. Arbak P, Karacan Ö, Erden F. AÜ Tıp Fakültesi Göğüs Hastalıkları Kliniğinde 1990-1994 y1lları arasında izlenen plevral sıvılı olguların özellikleri. Tuberk Toraks. 1998; 46: 256-63.

9. Bayrak MG, Erkan L, Uzun O, Findık S, Atıcı AG, Özkaya Ş. Plevral efuzyonlu 153 hastanın değerlendirilmesi. Solunum Hastalık. 2006; 17: 667.

10. Adams VI, Unni KK, Muhn RJ. Diffuse malignant mesotelioma of pleura. Diagnosis and survival in 92 cases. Cancer. 1986; 58: 1540-51.

11. Ardıç S, Artvinli M, Şahin AA, Özdemir N. Plevral efüzyonların tanısında tanı yöntemlerinin başarısı. Solunum. 1987; 12: 594-604.

12. Marel M, Stastny B, Melinova L. Diagnosis of pleural effusions: experience with clinical studies, 1986 to 1990 . Chest. $1995 ; 107: 1598-603$.

13. Polatlı M, Aysan T, Erdinç M, Günel Ö. Plevra sıvı sitolojisi ve plevra biyopsisinin tanı değeri. Tüberküloz ve Toraks. 1997; 45: 12-5. 